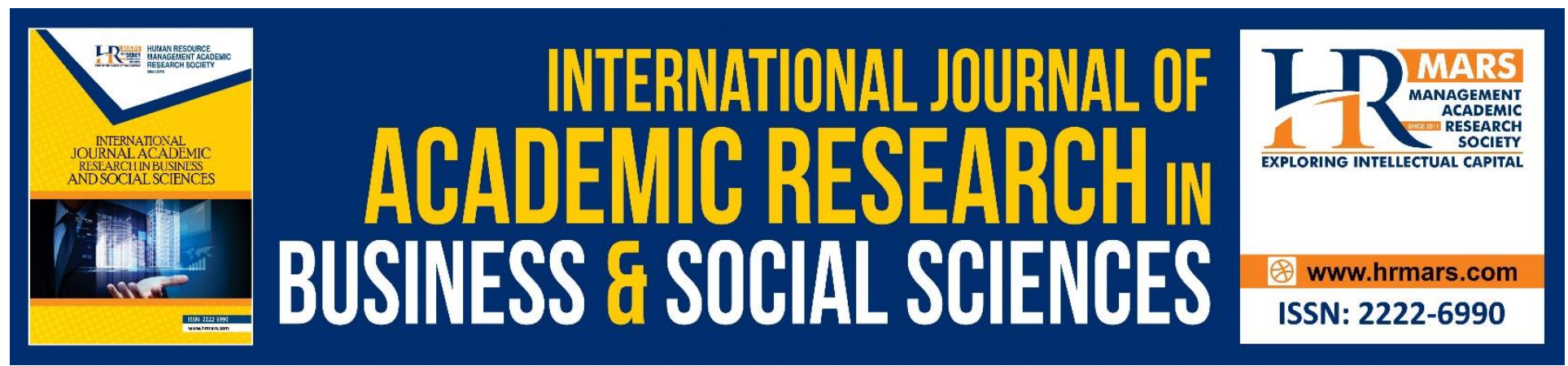

\title{
Concept Paper: A Multidimensional Assessment Approach of Talent Identification in Male Youth Malaysia Football Players
}

Khairul Sham Hanapiah, Ahmad Hashim \& Zulakbal Abd Karim

To Link this Article: http://dx.doi.org/10.6007/IJARBSS/v9-i11/6516

DOI: 10.6007/IJARBSS/v9-i11/6516

Received: 11 October 2019, Revised: 20 October 2019, Accepted: 30 October 2019

Published Online: 04 November 2019

In-Text Citation: (Hanapiah, Hashim, \& Karim, 2019)

To Cite this Article: Hanapiah, K. S., Hashim, A., \& Karim, Z. A. (2019). Concept Paper: A Multidimensional Assessment Approach of Talent Identification in Male Youth Malaysia Football Players. International Journal of Academic Research in Business and Social Sciences, 9(11), 33-49.

Copyright: (C) 2019 The Author(s)

Published by Human Resource Management Academic Research Society (www.hrmars.com)

This article is published under the Creative Commons Attribution (CC BY 4.0) license. Anyone may reproduce, distribute, translate and create derivative works of this article (for both commercial and non-commercial purposes), subject to full attribution to the original publication and authors. The full terms of this license may be seen at: $\underline{\text { http://creativecommons.org/licences/by/4.0/legalcode }}$

Vol. 9, No. 11, 2019, Pg. 33 - 49

http://hrmars.com/index.php/pages/detail/IJARBSS

JOURNAL HOMEPAGE

Full Terms \& Conditions of access and use can be found at http://hrmars.com/index.php/pages/detail/publication-ethics 


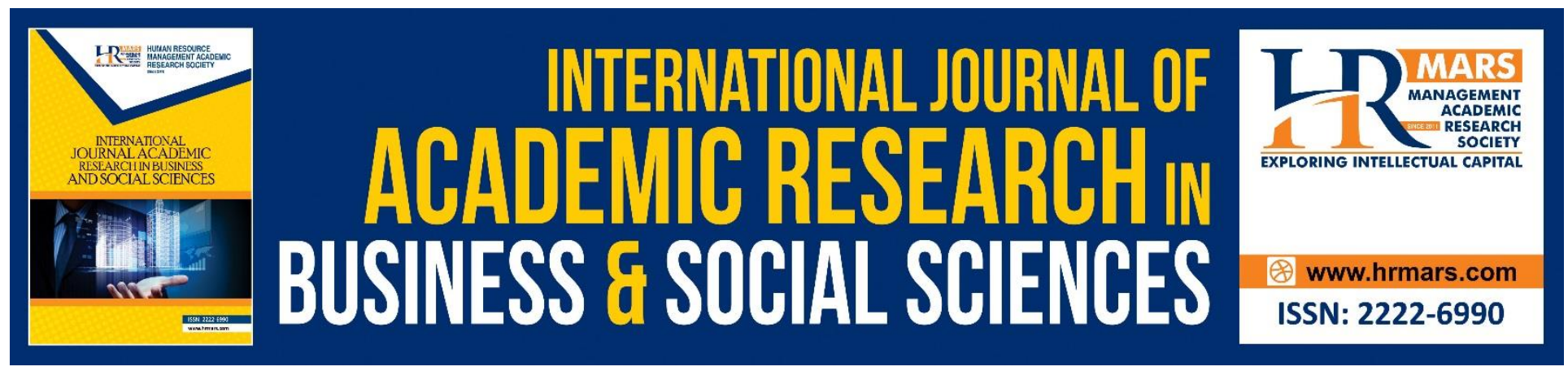

\title{
Concept Paper: A Multidimensional Assessment Approach of Talent Identification in Male Youth Malaysia Football Players
}

\author{
Khairul Sham Hanapiah, Ahmad Hashim \& Zulakbal Abd Karim \\ Faculty of Sports Science and Coaching, Sultan Idris Education University, Tanjong Malim, Perak, \\ Malaysia \\ Email: khairulsham@yahoo.com
}

\begin{abstract}
The main aim of this study is to identify the factors which influence playing ability performance in the identification process of young football talent as a whole. The evidences from the previous studies, Phase 1 National Football Development Plan:2014-2020 and the Roadmap of Malaysia Football Association: 2019-2030 shows that holistic approach in the process of identifying young talent is the main key in the development of a national football. The three main constraints were tasks, performers' and the environmental which involve the factors of training history, morphological, functional capacity, motor coordination, technical skills, tactical skills, psychological characteristics, biological maturity status, relative age effect and sociological which provide large influence to the football playing ability performance among the male youth football players. Both Newell (1986) constraint theory and Williams \& Reilly (2000) the football expertise prediction model are able to explain the relationship between variables which is related to the multidimensional assessment approach in identifying the young talent of football.

Keywords: Multidimensional Assessment Approach, Football Talent Identification, Training History, Morphological, Functional Capacity, Motor Coordination, Technical Skills, Tactical Skills, Psychological Characteristics, Biological Maturity Status, Relative Age Effect, Sociological and Playing Ability.

\section{Introduction}

The talent identification in football is a process of recognizing current participants with the potential to become elite players (Williams \& Reilly, 2000). The process of identification is very important in smaller countries which limited talent resource in developing a systematic structure to promote high performing talent for the selected sports development program (Vaeyens et al., 2009). The research to identify the talent in football has been studied since the 1990s (Morris, 2000). It is a complicated process since the demand of football is multifactorial in the higher level games (Reilly et al., 2000). It is also influenced by various factors such as the opportunity to
\end{abstract}


practice, free from injuries, guidance nature and coaching which is provided during the period of development, personality factor, social and culture (Reilly et al., 2000). According to Mccarthy \& Collins (2014), the identification of young talent who have high potential to achieve sucess in the senior level has become the biggest challenge faced by the federal government administration, sports club and coacheses. Effective talent identification system is monitored continuously by most of the sports association due to the rising financial and limited resource implication (Abbott \& Collins, 2002). Baker, Schorer, \& Wattie (2017) suggest that effective talent identification needs accurate prediction of specific sports demand to achieve optimum performance.

Previous studies shows that there are few changes in the modern football in terms of game structure, speed and play patterns which differentiate the football team whether competence and incompetence (Castellano, Casamichana, \& Lago, 2012; Lago-Penas, LagoBallesteros, \& Rey, 2011; Wallace \& Norton, 2013). The modern football evolution causes the changes in the young talent's characteristics who is seeking overall physical ability to complete a task during the period of games (Elferink-Gemser et. al, 2012; O'Connor, Larkin, \& Mark Williams, 2016; Reeves et al., 2018; Reeves et al., 2018; Wilson, 2017). This is because the activities in the modern football games needs high level of physical ability (Keller et al., 2018), physiological (Murr, Raabe, \& Honer, 2017), technical (Aquino et al., 2017), tactical (Hartigh et al., 2017) and psychological (Murr et al., 2018).

Lately, the usage of holistic approach towards the scientific method to identify young talent in football (Raya-Castellano \& Uriondo, 2015; Reilly et al., 2000) is emphasized. Usually, the coaches and the talent scouts will identify the novice talent who is potentially high based on the subjective talent criteria (Jokuschies, Gut, \& Conzelmann, 2017; Larkin \& O'Connor, 2017; Williams \& Reilly, 2000; Woods, Joyce, \& Robertson, 2015) in accordance to the respective game philosophy (Cushion, Ford, \& Williams, 2012; Sarmento et al., 2018). According to Meylan et al. (2010), the subjective evaluation process will be done based on emotions, knowledge and expertise which is considered valid by the coaches and talent scouts to differentiate the talented and less talented players. For example the coaches will determine who will be selected for the club, transferred to the higher training program or screen for the national team (Murr et al., 2017). However, the approach is rather subjective and it has created conflicts frequently in the process of evaluating talent (Christensen, 2009) and it is believed to be inconsistent (Williams \& Reilly, 2000). The latest trend shows that the subjective assessment of scouts or coaches is equipped with objective evaluations which provides a comprehensive perspective in the process of identifying and developing young football talent (Murr et al., 2017). Unnithan et al., (2012) reports that this approach helps in reducing the risk of losing potential young players which might not be realized by the coaches due to various factors. Besides that, the objective evaluations will be able to provide reference data to monitor the players performance development (PrietoAyuso, Pastor-Vicedo, \& Contreras-Jordan, 2017) and to analyses the effectiveness of the training program (Svensson \& Drust, 2005). Therefore, a comprehensive multidimensional approach has been adopted to talent identification in high-level youth football players.

\section{Background of the Study}


Football is a number one sports in Malaysia. The government has planned various initiative programmes related to the development of talent in the nation upon considering the deterioration of Malaysian football in the Asian and world arena. The football development programme begin in the year of 1989 with the establishment of Program Tunas Cemerlang which was administered by the National Sports Council of Malaysia with the collaboration of Malaysian School Sports Council. This programme is aimed to identify the potential talent among the players of age 13 and 14. In the year of 2006, Program Sukan Teras has replaced Program Tunas Cemerlang under the supervision of National Sports Council of Malaysia which is also in collaboration with the Football Association of Malaysia and Ministry of Education Malaysia to retrieve talented players from the age of 10 to 15 years old. However the approach has been amended upon the establishment of Program Sukan Prestasi Tinggi Sekolah in the year of 2008 under the surveillance of Ministry of Education Malaysia. This programme involve players between the age of 13 to 17 years old and they are placed in the District Training Centre, States Sports School and Malaysia Sports School. Besides that, the Talent Identification Programme with the collaboration of Ministry of Education Malaysia and Malaysian Ministry of Youth and Sports is also introduced to select the grassroot football talents to the States Sports School. Eventhough various programmes under the national football excellence centre has been conducted, the government through the Malaysian Cabinet Committee on Sports Development realise that the national football development needs a comprehensive and holistic transformation. Based on that, in the year of 2013 a long term plan which is the Phase 1 National Football Development:2014-2020 based on the philosophy or DNA of Malaysian football was introduced to develop the talent of players aged from seven till 17 years old throughout the nation. In this plan, the National Football Academy was rebranded to Mokhtar Dahari Football Academy to produce world class Malaysian football players. However, the Malaysian youth football team is yet to dominate Asia and international levels. Therefore in the year of 2018, the Football Association of Malaysia introduced a 2019-2030 Roadmap in adherence to "Malaysian Way" to provide a new approach to the holistic development of talent (Kementerian Belia dan Sukan Malaysia, 2014; Persatuan Bola Sepak Malaysia, 2018). In line with the demand of modern football games and the Malaysia National Football Development Plan, researchers have suggested conceptual framework of a multidimensional assessment approach of talent identification in male youth Malaysia football players.

\section{Literature Review}

Researchers referred to the existing literature associated with the factors that influence playing ability performance in identifying young football talents as a whole.

\section{Task Constraints}

Task constraints is the most important constraint because of its importance in learning which comprise of specialised task, activity rules and equipment normally used in the learning experience (Newell, 1986).

\section{Training History}


In a team sports such as football, a player needs learning pattern which is formal and informal to achieve success in the highest level. A successful player needs a continuous training process for a long period and it has to be systematic to achieve elite performance level (Ericsson, Krampe, \& Tesch-Romer, 1993; Gullich \& Emrich, 2012). The player development process to elite level is related to the role of deliberate practice and deliberate play (Ford et al., 2009).

Deliberate practice refers to the total training hours in a structured activity such as the practice with the coaches to elevate the performance (Helsen, Starkes, \& Hodges, 1998) while deliberate play refers to the total play time in an unstructured activity such as playing with teammates to maximize the fun (Cote, Baker, \& Abernethy, 2003). Previous studies shows that the players experience of involvement in the training activities and play during children to early adolescents is one of the important factor which influence the performance of elite level through deliberate practice and deliberate play (Ford et al., 2012; Forsman et al., 2016; Gullich et al., 2016; Hornig, Aust, \& Gullich, 2014; Roca, Williams, \& Ford, 2012).

\section{Performer's Constraints}

Performer's constraints illustrate the factors related to the human characteristics such as physical, physiological, cognitive and emotions (Newell, 1986).

\section{Morphological Factor}

Morphological is the study of human size, shape, proportion and composition to assist in the evaluation of growth and of the effects of exercise, performance and nutrition (Sanchez-Munoz, Zabala, \& Williams, 2012). Previous studies show that the measurement of morphological (stature, weight, body fat and body mass index) are commonly used to evaluated the physical characteristics of young football talents (Gouvea et al., 2017; Vandendriessche et al., 2012). Players' morphological characteristics could effects on functional capacity and technical performance (Malina et al., 2007; Matta et al., 2014). Therefore, the implication is that such measurements may assit in the identification of talents.

\section{Functional Capacity Factor}

Functional capacity is very important for a player to perform at a higher 'tempo'. This is because to achieve optimum performance in a competitive matches, a young players needs to have a combination of functional capacities such as aerobic capacity, anaerobic endurance, anaerobic power, speed, flexibility, agility, explosive power and muscular power (Murr et al., 2017). For example, according to Murr et al. (2017), strong core muscles and overall flexibility can further decrease the risk of injury and have a positive impact on performance. Muscle strength is mostly dynamic and explosive, and agility and speed are the most requested capacities in coordinated manoeuvres of dribbling, passing and ball control (Portes et al., 2015). Therefore, functional capacity will increase the physical and physiological capacity of player to execute explosive movement during match play.

A football game involves low to high intensity intermittent activity which requires players who have the aerobic and anaerobic system ability for energy channeling during match play (Reilly et al., 2000; Williams \& Reilly, 2000). This is because a player will be doing physical 
activities such as standing, walking, low and high intensity running for 90 minutes (Mohr, Krustrup, \& Bangsbo, 2003; Saward et al., 2015) for about 10 to 12 kilometers during games (Stolen et al., 2005). Bangsbo, Norregaard, \& Thorso (1991) reports that $90 \%$ of physical activities contributed by the aerobic energy system in combination with high intensity activities for seven minutes. Therefore, high amount of maximum oxygen intake $\left(\mathrm{VO}_{2} \max \right)$ is needed by a player in a competitive matches. Helgerud et al. (2001) found out that $\mathrm{VO}_{2}$ max amount for junior male football player is between $58.1 \pm 4.5$ to $64.3 \pm 3.9 \mathrm{ml} \cdot \mathrm{min}^{-1} \cdot \mathrm{kg}^{-1}$. Therefore it is clear that aerobic capacity $\left(\mathrm{VO}_{2} \mathrm{max}\right)$ is a relevant key to identify the maximum oxygen intake which is inhaled and used by the body during games.

Besides that anaerobic energy system is also used for short activities within two minutes which require a little or without oxygen using adenosine-triphosphate (ATP) in the body as the main energy producing source (Bangsbo, 2003). In a 90 minutes match, elite players will run about 10 kilometers with average running intensity which nearly approaching the anaerobic threshold (80-90\% of maximum heart rate) (Stolen et al., 2005). The many intense actions (>100) during a game indicate that the rate of anaerobic energy turnover is also high during game periods, with a significant rate of utilization of creatine phosphate and lactate accumulation (Bangsbo, 2014). Therefore, it is likely that functional capacity correlates of work-rate during games have gained in importance in the context of fitness for football.

\section{Motor Coordination Factor}

Motor coordination is another player characteristic used in talent identification. It can be described as multiple body effectors (i.e. muscles, joints and limbs) optimally working together to achieve goal directed human movement in the most efficient way (Rommers et al., 2018). Generic motor coordination serves as the basis to acquire more specialized sport specific motor coordination skills (Hulteen et al., 2015). Previous studies highlights three KorperkoordinationsTest fur Kinder (KTK) (i.e. jumping sideways, moving sideways, balancing backwards)(Kiphard \& Schilling, 2007) to assess generic motor coordination and the UGent dribbling test (Vandendriessche et al., 2012) for soccer specific motor coordination are included in the talent identification process in youth soccer (Deprez et al., 2015; Fransen et al., 2017). Therefore, the assessment of players' performance on generic motor coordination tests seems to be more useful to discover their real aptitude or potential to pick up new technical skills (Pion et al., 2014; Vandendriessche et al., 2012).

\section{Technical Skill Factor}

The motor skills required to successfully control, pass, dribble and shoot the ball at goal are fundamental skills of the soccer player (Ali, 2011). The need of possessing high technical skills are in line with the modern football games for the increase of ball speed, the duration and frequency of play and stop periods, player density and passing rates during a high performing matches such as FIFA World Cup Finals (Castellano et al., 2012; Wallace \& Norton, 2013), UEFA Champions League (Lago-Penas et al., 2011), English Premier League (Salvo et al., 2009) and Spanish La Liga (Dellal et al., 2011). Rampinini et al. (2009) found out that the winning team in Italian Serie A has the advantage of technical skill performance such as ball control, short passing, long passing, 
crossing, heading, tackling, dribbling and shooting during the period of games. Therefore, specific football skill test is an instrument to set the potential technical skill of a player based on a real game situations (Rubajczyk \& Rokita, 2015). Technical skill proficiency can increase the ability of right movement at the right moment during games (Keller et al., 2016).

\section{Tactical Skill Factor}

Tactical skills are fundamental to high-level soccer performance. Tactical skills involves continuous interaction between attacking teams, defending team and ball movement (Fernandez-rio \& Mendez-gimenez, 2014). According to Elferink-Gemser et al. (2004), tactical skill related to the way of player executing the right action at the right moment. The attacking team puts up initiative to do direct, possession, counter attack, total soccer and crossing while defending team tries to provide high and low pressure to the opponents throughout the period of matches (Fernandez-Navarro, Fradua, Zubillaga, Ford, \& McRobert, 2016). The ability of each player to make an accurate and quick decision-making is much needed to face different game situations (Kannekens, Elferink-gemser, \& Visscher, 2009). Previous studies show that a winning team needs a player who is competence in tactical skills including declarative and procedural knowledge of actions within the context of the game (Elferink-Gemser et al., 2004; Grehaigne, Godbout, \& Bouthier, 1999; Kannekens, Elferink-Gemser, \& Visscher, 2011; Kannekens et al., 2009). Skilled players often possess a 'game intelligence' that allows them to analyses major features of their opponent's play. Therefore, the measurement of tactical skills provides a promising approach to talent identification.

\section{Psychological Factor}

Previous studies show that psychological factors plays an important role in the process of identifying and development of young football talent (Feichtinger \& Honer, 2014; MacNamara \& Collins, 2015; Morris, 2000; Murr et al., 2018). According to Williams \& Reilly (2000), there are different psychological characteristics between talented and less talented players in terms of development in learning, training and competition. Research evidence indicates that elite youth football players have personality traits such as anxiety control, mental preparation, team orientation, concentration, motivation and self-confidence that facilitate learning/training and competition (Forsman et al., 2016; Huijgen et al., 2014; Williams \& Reilly, 2000). According to MacNamara \& Collins (2012), psychological characteristics of developing excellence equip aspiring elites with the necessary mental skills, attitudes, and emotions to cope with the inevitable challenges of the development pathway, as well as underpinning their capacity to make the most of their innate abilities. Therefore, psychological factors can be considered as the power of thinking may influence the young talent potential and performance in games.

\section{Environmental Constraints}

Environmental constraints refers to confounding factors which influence young players development namely growth and maturity (Gray \& Plucker, 2010) as well as social network such as socio-cultural environment, principles and influence of social class towards them (Newell, 1986). 


\section{Biological Maturity Status}

Talent identification programs are traditionally conducted during adolescence (Vandendriessche et al., 2012). According to Pearson et al., (2006), adolescence level is the dynamic trial period in the physiological ability, physical parameters, sexual characteristics and social interaction. Talent development process from junior to elite level is closely related with physical growth and interaction, biological maturity, behavioral development and specific sports demand (Malina \& Katzmarzyk, 2006; Malina et al., 2015; Pearson et al., 2006). Generally, adolescent biological maturity progress level is different between individuals and they are categorized according to early, average and late maturity groups (Malina, Bounchard, \& Bar-Or, 2004).

Malina et al., (2015) show that adolescent boys aged 13 and 15 years who are early maturity may afford an advantage in the physical and functional characteristics compared to those who average and later maturing peers. Changes in body size, composition and functional capacities (i.e., strength, power, aerobic) that occur with puberty and the growth spurt in males are well documented (Malina et al., 2004). Previous studies show that non-invasive technique is applied to predicted maturity offset and age at peak height velocity among adolescent male football players (Buchheit \& Mendez-Villanueva, 2014; Malina et al., 2004; Malina et al., 2012; Rommers et al., 2018).

\section{Relative Age Effect}

Previous studies show that Europe elite clubs is more prone to choose players who achieve early maturing due to the advantage of body size, body composition, functional capacity and specific sports skills to succeed in the long term (Brustio et al., 2018; Gonzalez-Víllora, Pastor-Vicedo, \& Cordente, 2015; Jimenez \& Pain, 2008; Mujika et al., 2009). This phenomenon will create relative age effect due to the differences in the physical development, emotions and intellectual between juniors and seniors in the same team (Jimenez \& Pain, 2008). According to Helsen, Van Winckel, $\&$ Williams (2005), relative age effect refers to the age difference between individuals in each age group which influence the performance. Usually, birthday date will be classified according to four quartile in a year according to the school season and sports calendar (Barnsley, Thompson, \& Legault, 1992). The effect of birth date has been shown that those who are born late in the selection year are more likely to drop out of these sports than players who are born early in the selection year (Romann et al., 2018).

\section{Sociological}

The developmental of talented players requires appropriate social and environmental support mechanisms. According to Williams \& Reilly (2000), social support is an important element may have an impact on young players values, beliefs, emotions, attitude and dedication towards football. Talented youngsters may see the parents, coaches, team-mates, school teachers, friends and peers as significant persons to career progression, achievement and success within their sport (Reilly, Williams, \& Richardson, 2003). Rees \& Hardy (2000) show that social support is closely related to group cohesion, coping with competitive stress, slumps in performance, burnout, vulnerability to injury, the etiology and recovery from injury, leadership styles and 
performance. Socio-economic status can also affect a young player's development. For example, the financial constraints limiting access to coaching and training sessions, games, facilities, kit, equipment plus various other supporting considerations may offer the middle and upper classes a competitive advantage (Reeves et al., 2018). Therefore, sociological considerations place greater emphasis on the nurturing of talent, environmental factors and the availability of opportunity.

\section{Football Playing Ability}

Football playing ability refers to the coaches's subjective evaluation towards the overall ability of players' (Lovell et al., 2017; Sieghartsleitner et al., 2019). The coaches used a visual analog scale between 0 and 100 points in the rating of players' in game performance (Lovell et al., 2017; Sieghartsleitner et al., 2019).

\section{Methodology}

This paper uses a qualitative approach. This is done by reviewing all the relevant literature that related to the topic from various database. In reviewing the literature, researchers has developed research question throughout this study. For instance, "what are the primary and secondary factors which influences talent identification and development in elite male youth football players?" Researchers also proposed the conceptual framework of multidimensional assessment approach of talent identification in male youth Malaysia football players.

\section{Proposed Conceptual Framework}

The proposed of multidimensional assessment approach framework for the talent identification in male youth Malaysia football players is illustrated in Figure 1. This conceptual framework was developed based on previous studies, the Newell (1986) constraint theory and Williams \& Reilly (2000) football expertise prediction model. Research evidence highlights that the training history, morphological, functional capacity, motor coordination, technical skills, tactical skills, psychological characteristics, biological maturity status, relative age effect and sociological factors could discriminate between talented and less talented youth football players. 


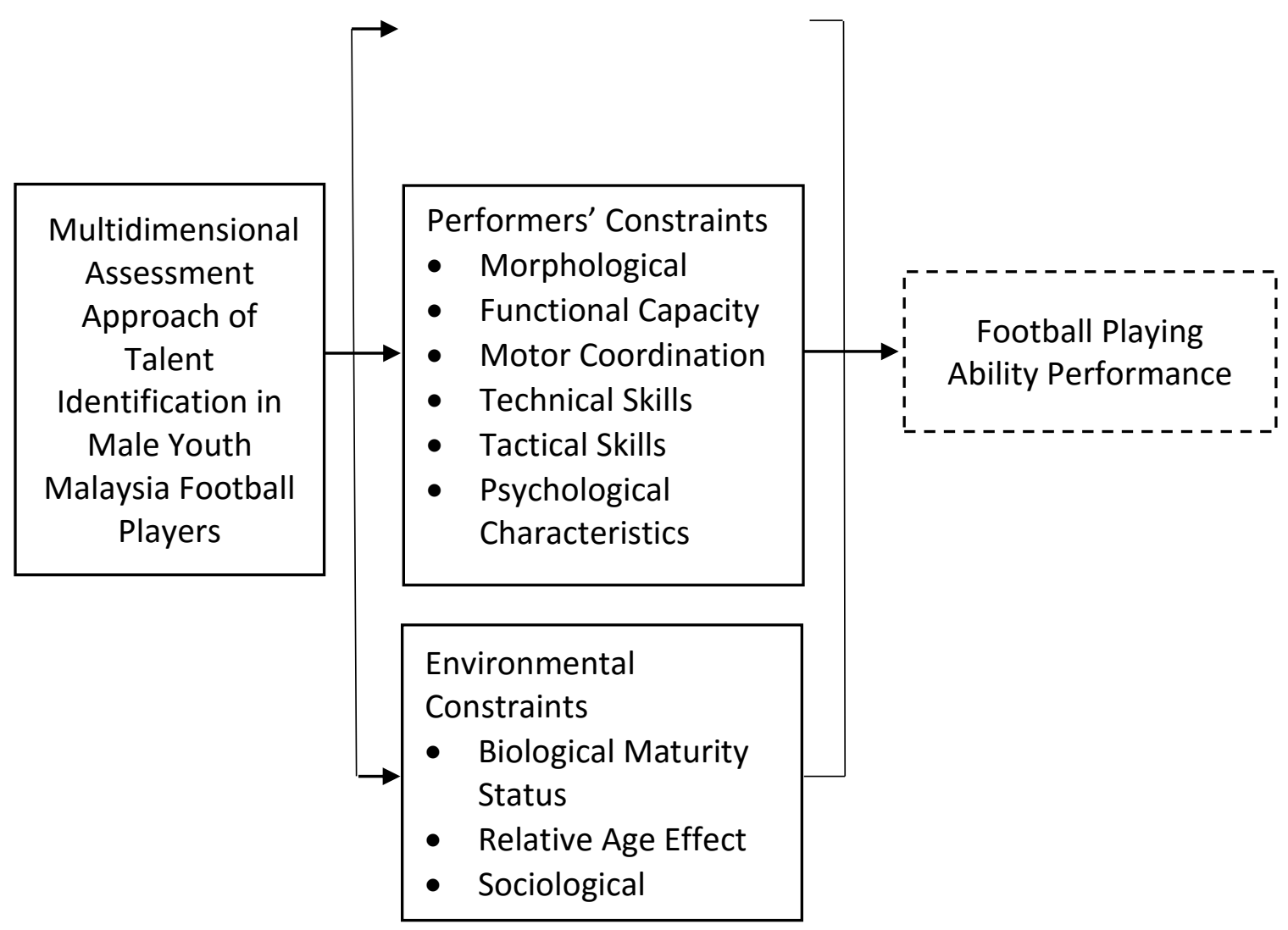

Figure 1. Proposed Conceptual Framework Multidimensional Assessment Approach of Talent Identification in Male Youth Malaysia Football Players

\section{Recommendation and Conclusion}

Research evidence show that various factors influence playing ability performance in identifying young football talents as a whole. These factors can be divided into primary influences towards performance and secondary influences through interaction with other factors. The primary influences are the task and performer's constraints while secondary influence is the environmental constraint. This multidimensional assessment approach in this conceptual framework can discriminate between talented and less talented players, promoting high performing young talents to the elite programmes of national football and better comprehension of the assessment practise of young football talents identification process. Descriptive studies with multidimensional evaluations are necessary to investigate whether all the factors has larger impact on the playing ability performances in talent identification of male youth Malaysia football players.

\section{Corresponding Authors}


INTERNATIONAL JOURNAL OF ACADEMIC RESEARCH IN BUSINESS AND SOCIAL SCIENCES

Vol. 9, No. 11, November, 2019, E-ISSN: 2222-6990 @ 2019 HRMARS

Khairul Sham Hanapiah

PhD Candidate, Sultan Idris Education University, Faculty of Sports Science and Coachesing, 35900 Tanjong Malim, Perak, Malaysia

Email: khairulsham@yahoo.com

\section{References}

Abbott, A., \& Collins, D. (2002). A theoretical and empirical analysis of a "state of the art" talent identification model. High Ability Studies, 13(2), 157-178.

Ali, A. (2011). Measuring soccer skill performance: A review. Scandinavian Journal of Medicine and Science in Sports, 21(2), 170-183.

Aquino, R., Puggina, E. F., Alves, I. S., \& Garganta, J. (2017). Skill-related performance in soccer: A systematic review. Human Movement, 18(5), 3-24.

Baker, J., Schorer, J., \& Wattie, N. (2017). Compromising talent: Issues in identifying and selecting talent in sport. Quest, 70(1), 48-63.

Bangsbo, J. (2003). Fitness training in soccer: A scientific approach. Spring City, PA: Reedswain Publishing.

Bangsbo, J. (2014). Physiological demands of football. Sports Science Exchange, 27(125), 1-6.

Bangsbo, J., Norregaard, L., \& Thorso, F. (1991). Activity profile of competition soccer. Canadian Journal of Sport Sciences, 16(2), 110-116.

Barnsley, R. H., Thompson, A. H., \& Legault, P. (1992). Family planning: Football style. The relative age effect in football. International Review for the Sociology of Sport, 27(1), 77-87.

Brustio, P. R., Lupo, C., Ungureanu, A. N., Frati, R., Rainoldi, A., \& Boccia, G. (2018). The relative age effect is larger in Italian soccer top-level youth categories and smaller in Serie A. PLoS ONE, 13(4), 1-12.

Buchheit, M., \& Mendez-Villanueva, A. (2014). Effects of age, maturity and body dimensions on match running performance in highly trained under-15 soccer players. Journal of Sports Sciences, 32(13), 1271-1278.

Castellano, J., Casamichana, D., \& Lago, C. (2012). The use of match statistics that discriminate between successful and unsuccessful soccer teams. Journal of Human Kinetics, 31(1), 139147.

Christensen, M. K. (2009). "An eye for talent": Talent identification and the "practical sense" of top-level soccer coaches. Sociology of Sport Journal, 26(3), 365-382.

Cote, J., Baker, J., \& Abernethy, B. (2003). From play to practice: A developmental framework for the acquisition of expertise in team sport. In J. L. Starkes \& K. A. Ericsson (Eds.), Expert performance in sports: Advances in research on sport expertise (pp. 89-113). Champaign, IL: Human Kinetics.

Cushion, C., Ford, P. R., \& Williams, A. M. (2012). Coach behaviours and practice structures in youth soccer: Implications for talent development. Journal of Sports Sciences, 30(15), 16311641.

Dellal, A., Chamari, K., Wong, D. P., Ahmaidi, S., Keller, D., Barros, R., Bisciotti, G. N., \& Carling, C. (2011). Comparison of physical and technical performance in European soccer match-play: Fa Premier League and La Liga. European Journal of Sport Science, 11(1), 51-59. 
Hartigh, D. R. J. R., Steen, V. D. S., Hakvoort, B., Frencken, W. G. P., \& Lemmink, K. A. P. M. (2017). Differences in game reading between selected and non-selected youth soccer players. Journal of Sports Sciences, 36(4), 422-428.

Deprez, D. N., Fransen, J., Lenoir, M., Philippaerts, R. M., \& Vaeyens, R. (2015). A retrospective study on anthropometrical, physical fitness, and motor coordination characteristics that influence dropout, contract status, and first-team playing time in high-level soccer players aged eight to eighteen years. Journal of Strength and Conditioning Research, 29(6), 16921704.

Salvo, D. V., Gregson, W., Atkinson, G., Tordoff, P., \& Drust, B. (2009). Analysis of high intensity activity in premier league soccer. International Journal of Sports Medicine, 30(3), 205-212.

Elferink-Gemser, M. T., Visscher, C., Richart, H., \& Lemmink, K. A. P. M. (2004). Development of the tactical skills inventory for sports. Perceptual and Motor Skills, 99(3), 883-895.

Elferink-Gemser, Marije T., Huijgen, B. C., Coelho-E-Silva, M., Lemmink, K. A. P. M., \& Visscher, C. (2012). The changing characteristics of talented soccer players - A decade of work in Groningen. Journal of Sports Sciences, 30(15), 1581-1591.

Ericsson, K. A., Krampe, R. T., \& Tesch-Romer, C. (1993). The role of deliberate practice in the acquisition of expert performance. Psychological Review, 100(3), 363-406.

Feichtinger, P., \& Honer, O. (2014). Psychological diagnostics in the talent development program of the German Football Association: Psychometric properties of an internet-based test battery. Sportwissenschaft, 44(4), 203-213.

Fernandez-Navarro, J., Fradua, L., Zubillaga, A., Ford, P. R., \& McRobert, A. P. (2016). Attacking and defensive styles of play in soccer: Analysis of Spanish and English elite teams. Journal of Sports Sciences, 34(24), 2195-2204.

Fernandez-rio, J., \& Mendez-gimenez, A. (2014). Talent detection and development in soccer: A review. Journal of Sport and Health Research, 6(1), 7-18.

Figueiredo, A. J., Coelho e Silva, M. J., \& Malina, R. M. (2011). Predictors of functional capacity and skill in youth soccer players. Scandinavian Journal of Medicine and Science in Sports, 21(3), 446-454.

Ford, P. R., Carling, C., Garces, M., Marques, M., Miguel, C., Farrant, A., Stenling, A., Moreno, J., Gall, L. F., Holmstrom, S., Salmela, J. H., \& Williams, A. M. (2012). The developmental activities of elite soccer players aged under-16 years from Brazil, England, France, Ghana, Mexico, Portugal and Sweden. Journal of Sports Sciences, 30(15), 1653-1663.

Ford, P. R., Ward, P., Hodges, N. J., \& Williams, A.M. (2009). The role of deliberate practice and play in career progression in sport: The early engagement hypothesis. High Ability Studies, 20(1), 65-75.

Forsman, H., Blomqvist, M., Davids, K., Konttinen, N., \& Liukkonen, J. (2016). The role of sportspecific play and practice during childhood in the development of adolescent Finnish team sport athletes. International Journal of Sports Science and Coaching, 11(1), 69-77.

Forsman, H., Blomqvist, M., Davids, K., Liukkonen, J., \& Konttinen, N. (2016). Identifying technical, physiological, tactical and psychological characteristics that contribute to career progression in soccer. International Journal of Sports Science and Coaching, 11(4), 505-513.

Forsman, H., Grasten, A., Blomqvist, M., Davids, K., Liukkonen, J., \& Konttinen, N. (2015). 
Development and validation of the perceived game-specific soccer competence scale. Journal of Sports Sciences, 34(15), 1319-1327.

Fransen, J., Bennett, K. J., Woods, C. T., French-Collier, N., Deprez, D., Vaeyens, R., \& Lenoir, M. (2017). Modelling age-related changes in motor competence and physical fitness in highlevel youth soccer players: Implications for talent identification and development. Science and Medicine in Football, 1(3), 203-208.

Gonzalez-Villora, S., Pastor-Vicedo, J. C., \& Cordente, D. (2015). Relative age effect in UEFA championship soccer players. Journal of Human Kinetics, 47(1), 237-248.

Gouvea, M. A., Cyrino, E. S., Valente-Dos-Santos, J., Ribeiro, A. S., Silva, D. R. P. da, Ohara, D., Coelho-E-Silva, M.J., \& Ronque, E. R. V. (2017). Comparison of skillful vs. less skilled young soccer players on anthropometric, maturation, physical fitness and time of practice. International Journal of Sports Medicine, 38(5), 384-395.

Gray, H. J., \& Plucker, J. A. (2010). '"She's a natural"': Identifying and developing athletic talent. Journal for the Education of the Gifted, 33(3), 361-380.

Grehaigne, J. F., Godbout, P., \& Bouthier, D. (1999). The foundations of tactics and strategy in team sports. Journal of Teaching in Physical Education, 18, 159-174.

Gullich, A., \& Emrich, E. (2012). Considering long-term sustainability in the development of world class success. European Journal of Sport Science, 14(sup1), S383-S397.

Gullich, A., Kovar, P., Zart, S., \& Reimann, A. (2016). Sport activities differentiating match-play improvement in elite youth footballers-a 2-year longitudinal study. Journal of Sports Sciences, 35(3), 207-215.

Helgerud, J., Engen, L. C., Wisloff, U., \& Hoff, J. (2001). Aerobic endurance training improves soccer performance. Medicine \& Science in Sports \& Exercise, 33(11), 1925-1931.

Helsen, W. F., Starkes, J. L., \& Hodges, N. J. (1998). Team sports and the theory of deliberate practice. Journal of Sport \& Exercise Psychology, 20(1), 12-34.

Helsen, W. F., Winckel, V. J., \& Williams, A. M. (2005). The relative age effect in youth soccer across Europe. Journal of Sports Sciences, 23(6), 629-636.

Hornig, M., Aust, F., \& Gullich, A. (2016). Practice and play in the development of German toplevel professional football players. European Journal of Sport Science, 16(1), 96-105.

Huijgen, B. C. H., Elferink-Gemser, M. T., Lemmink, K. A. P. M., \& Visscher, C. (2014). Multidimensional performance characteristics in selected and deselected talented soccer players. European Journal of Sport Science, 14(1), 2-10.

Hulteen, R. M., Lander, N. J., Morgan, P. J., Barnett, L. M., Robertson, S. J., \& Lubans, D. R. (2015). Validity and reliability of field-based measures for assessing movement skill competency in lifelong physical activities: A systematic review. Sports Medicine, 45(10), 1443-1454.

Jimenez, I. P., \& Pain, M. (2008). Relative age effect in Spanish association football: Its extent and implications for wasted potential. Journal of Sports Sciences, 26(10), 995-1003.

Jokuschies, N., Gut, V., \& Conzelmann, A. (2017). Systematizing coaches' 'eye for talent": Player assessments based on expert coaches' subjective talent criteria in top-level youth soccer.' International Journal of Sports Science \& Coaching, 12(5), 565-576.

Kannekens, R., Elferink-Gemser, M. T., \& Visscher, C. (2011). Positioning and deciding: Key factors for talent development in soccer. Scandinavian Journal of Medicine and Science in Sports, 
21(6), 846-852.

Kannekens, R., Elferink-gemser, M. T., \& Visscher, C. (2009). Tactical skills of world-class youth soccer teams. Journal of Sports Sciences, 27(8), 807-812.

Keller, B. S., Raynor, A. J., Bruce, L., \& Iredale, F. (2016). Technical attributes of Australian youth soccer players: Implications for talent identification. International Journal of Sports Science and Coaching, 11(6), 819-824.

Keller, B. S., Raynor, A. J., Bruce, L., \& Iredale, F. (2018). Physical and anthropometrical attributes of Australian youth soccer players. International Journal of Sports Science \& Coaching, 13(5), 787-793.

Kementerian Belia dan Sukan Malaysia. (2014). Pelan pembangunan bola sepak negara fasa 1: 2014-2020. Putrajaya: Kementerian Belia dan Sukan Malaysia.

Kiphard, E. J., \& Schilling, F. (2007). Korperkoordinationstest fur Kinder: KTK. Gottingen: Beltz Test. Lago-Penas, C., Lago-Ballesteros, J., \& Rey, E. (2011). Differences in performance indicators between winning and losing teams in the UEFA champions league. Journal of Human Kinetics, 27(1), 135-146.

Larkin, P., \& O'Connor, D. (2017). Talent identification and recruitment in youth soccer: Recruiter's perceptions of the key attributes for player recruitment. PLOS ONE, 12(4), 1-15.

Lovell, T. W. J., Bocking, C. J., Fransen, J., \& Coutts, A. J. (2017). A multidimensional approach to factors influencing playing level and position in a school-based soccer programme. Science and Medicine in Football, 2(3), 237-245.

MacNamara, A., \& Collins, D. (2012). Do mental skills make champions? Examining the discriminant function of the psychological characteristics of developing excellence questionnaire. Journal of Sports Sciences, 31(7), 736-744.

MacNamara, A., \& Collins, D. (2015). Profiling, exploiting, and countering psychological characteristics in talent identification and development. The Sport Psychologist, 29(1), 7381.

Malina, R. M., Bounchard, C., \& Bar-Or, O. (2004). Growth, maturation and physical activity (2nd ed.). Champaign, III: Human Kinetics.

Malina, R. M., Eisenmann, J. C., Cumming, S. P., Ribeiro, B., \& Aroso, J. (2004). Maturityassociated variation in the growth and functional capacities of youth football (soccer) players 13-15 years. European Journal of Applied Physiology, 91((5-6)), 555-562.

Malina, R. M., \& Katzmarzyk, P. T. (2006). Physical activity and fitness in an international growth standard for preadolescent and adolescent children. Food and Nutrition Bulletin, 27(4), 295313.

Malina, R. M., Ribeiro, B., Aroso, J., \& Cumming, S. P. (2007). Characteristics of youth soccer players aged 13-15 years classified by skill level. British Journal of Sports Medicine, 41(5), 290-295.

Malina, R. M., Rogol, A. D., Cumming, S. P., Coelho e Silva, M. J., \& Figueiredo, A. J. (2015). Biological maturation of youth athletes: Assessment and implications. British Journal of Sports Medicine, 49(13), 852-859.

Malina, R. M., Silva, M. J. C. E., Figueiredo, A. J., Carling, C., \& Beunen, G. P. (2012). Interrelationships among invasive and non-invasive indicators of biological maturation in 
adolescent male soccer players. Journal of Sports Sciences, 30(15), 1705-1717.

Matta, M. D. O., Fiqueiredo, A. J. B., Garcia, E. S., Werneck, F. Z., \& Seabra, A. (2014). Morphological and maturational predictors of technical performance in young soccer players. Motriz Rio Claro, 20(3), 280-285.

Mccarthy, N., \& Collins, D. (2014). Initial identification \& selection bias versus the eventual confirmation of talent: Evidence for the benefits of a rocky road? Journal of Sports Sciences, 32(17), 1604-1610.

Meylan, C., Cronin, J., Oliver, J., \& Hughes, M. (2010). Talent identification in soccer: The role of maturity status on physical, physiological and technical characteristics. International Journal of Sports Science \& Coaching, 5(4), 571-592.

Mohr, M., Krustrup, P., \& Bangsbo, J. (2003). Match performance of high-standard soccer players with special reference to development of fatigue. Journal of Sports Sciences, 21(7), 519-528.

Morris, T. (2000). Psychological characteristics and talent identification in soccer. Journal of Sports Sciences, 18(9), 715-726.

Mujika, I., Vaeyens, R., Matthys, S. P. J., Santisteban, J., Goiriena, J., \& Philippaerts, R. (2009). The relative age effect in a professional football club setting. Journal of Sports Sciences, 27(11), 1153-1158.

Murr, D., Feichtinger, P., Larkin, P., O’Connor, D., \& Honer, O. (2018). Psychological talent predictors in youth soccer: A systematic review of the prognostic relevance of psychomotor, perceptual-cognitive and personality-related factors. PloS One, 13(10), 1-24.

Murr, D., Raabe, J., \& Honer, O. (2017). The prognostic value of physiological and physical characteristics in youth soccer: A systematic review. European Journal of Sport Science, 18(1), 62-74.

Newell, K. M. (1986). Constraints on the development of coordination. In M. G. Wade \& H. T. A. Whiting (Eds.), Motor development in children: Aspects of coordination and control (pp. 341360). Dordrecht: Martinus Nijhoff Publishers.

O'Connor, D., Larkin, P., \& Williams, M. A. (2016). Talent identification and selection in elite youth football: An Australian context. European Journal of Sport Science, 16(7), 837-844.

Pearson, D. T., Naughton, G. A., \& Torode, M. (2006). Predictability of physiological testing and the role of maturation in talent identification for adolescent team sports. Journal of Science and Medicine in Sport, 9(4), 277-287.

Persatuan Bola Sepak Malaysia. (2018). FAM roadmap: 2019-2030. Petaling Jaya: Persatuan Bola Sepak Malaysia.

Philippaerts, R. M., Vaeyens, R., Janssens, M., Renterghem, V. B., Matthys, D., Craen, R., Bourgois, J., Vrijens, G., Beunen, G., \& Malina, R. M. (2006). The relationship between peak height velocity and physical performance in youth soccer players. Journal of Sports Sciences, 24(3), 221-230.

Pion, J., Segers, V., Fransen, J., Debuyck, G., Deprez, D., Haerens, L., Vaeyens, R., Philippaerts, R., \& Lenoir, M. (2014). Generic anthropometric and performance characteristics among elite adolescent boys in nine different sports. European Journal of Sport Science, 15(5), 357-366.

Portes, L. A., Canhadas, I. L., Silva, R. L. P., \& Oliveira, N. C. D. (2015). Anthropometry and fitness of young elite soccer players by field position. Sport Sciences for Health, 11(3), 321-328. 
Prieto-Ayuso, A., Pastor-Vicedo, J., \& Contreras-Jordan, O. (2017). Content validity and psychometric properties of the nomination scale for identifying football talent (NSIFT): Application to coaches, parents and players. Sports, 5(2), 1-14.

Rampinini, E., Impellizzeri, F. M., Castagna, C., Coutts, A. J., \& Wisloff, U. (2009). Technical performance during soccer matches of the Italian Serie A league: Effect of fatigue and competitive level. Journal of Science and Medicine in Sport, 12(1), 227-233.

Raya-Castellano, P. E., \& Uriondo, L. F. (2015). A review of the multidisciplinary approach to develop elite players at professional football academies: Applying science to a professional context. International Journal of Performance Analysis in Sport, 15(1), 1-19.

Rees, T., \& Hardy, L. (2000). An investigation of the social support experiences of high-level sports performers. The Sport Psychologist, 14(4), 327-347.

Reeves, M. J., Littlewood, M. A., Mcrobert, A. P., \& Simon, J. (2018). The nature and function of talent identification in junior-elite football in English category one academies. Soccer \& Society, 19 (8), 1122-1134.

Reeves, M. J., Mcrobert, A. P., Littlewood, M. A., \& Simon, J. (2018). A scoping review of the potential sociological predictors of talent in junior-elite football: $2000-2016$. Soccer \& Society, 19(8), 1085-1105.

Reeves, M. J., Roberts, S. J., McRobert, A. P., \& Littlewood, M. A. (2018). Factors affecting the identification of talented junior-elite footballers: A case study. Soccer and Society, 19 (8), 1106-1121.

Reilly, T., Bangsbo, J., Franks, A., Reilly, T., Bangsbo, J., \& Franks, A. (2000). Anthropometric and physiological predispositions for elite soccer. Journal of Sports Sciences, 18(9), 669-683.

Reilly, T, Williams, A. M., Nevill, A., \& Franks, A. (2000). A multidisciplinary approach to talent identification in soccer. Journal of Sports Sciences, 18(9), 695-702.

Reilly, Thomas, Williams, A. M., \& Richardson, D. (2003). Identifying talented players. In Thomas Reilly \& A. M. Williams (Eds.), Science and soccer (2nd ed., pp. 307-326).London: Routledge.

Roca, A., Williams, A. M., \& Ford, P. R. (2012). Developmental activities and the acquisition of superior anticipation and decision making in soccer players. Journal of Sports Sciences, 30(15), 1643-1652.

Romann, M., Rossler, R., Javet, M., \& Faude, O. (2018). Relative age effects in Swiss talent development - A nationwide analysis of all sports. Journal of Sports Sciences, 36(17), 20252031.

Rommers, N., Mostaert, M., Goossens, L., Vaeyens, R., Witvrouw, E., Lenoir, M., \& D'Hondt, E. (2018). Age and maturity related differences in motor coordination among male elite youth soccer players. Journal of Sports Sciences, 37(2), 196-203.

Rubajczyk, K., \& Rokita, A. (2015). Relationships between results of soccer-specific skill tests and game-related soccer skill assessment in young players aged 12 and 15 years. Trends in Sport Sciences, 4(22), 197-206.

Russell, M., Benton, D., \& Kingsley, M. (2010). Reliability and construct validity of soccer skills tests that measure passing, shooting, and dribbling. Journal of Sports Sciences, 28(13), 13991408.

Sanchez-Munoz, C., Zabala, M., \& Williams, K. (2012). Anthropometric variables and its usage to 
characterise elite youth athletes. In V. R. Preedy (Eds.), Handbook of anthropometry: Physical measures of human form in health and disease (pp. 1865-1888). New York, NY: Springer.

Sarmento, H., Anguera, M. T., Pereira, A., \& Araujo, D. (2018). Talent identification and development in male football: A systematic review. Sports Medicine, 48(4), 907-931.

Saward, C., Morris, J. G., Nevill, M. E., Nevill, A. M., \& Sunderland, C. (2015). Longitudinal development of match-running performance in elite male youth soccer players. Scandinavian Journal of Medicine and Science in Sports, 26 (8), 993-942.

Sieghartsleitner, R., Zuber, C., Zibung, M., \& Conzelmann, A. (2019). Science or coaches' eye?Both! Beneficial collaboration of multidimensional measurements and coach assessments for efficient talent selection in elite youth football. Journal of Sports Science and Medicine, 18(1), 32-43.

Stolen, T., Chamari, K., Castagna, C., \& Wisloff, U. (2005). Physiology of soccer: An update. Sports Medicine, 35(6), 501-536.

Svensson, M., \& Drust, B. (2005). Testing soccer players. Journal of Sports Sciences, 23(6), 601618.

Unnithan, V., White, J., Georgiou, A., Iga, J., \& Drust, B. (2012). Talent identification in youth soccer. Journal of Sports Sciences, 30(15), 1719-1726.

Vaeyens, R., Gullich, A., Warr, C. R., \& Philippaerts, R. (2009). Talent identification and promotion programmes of Olympic athletes. Journal of Sports Sciences, 27(13), 1367-1380.

Vandendriessche, J. B., Vaeyens, R., Vandorpe, B., Lenoir, M., Lefevre, J., \& Philippaerts, R. M. (2012). Biological maturation, morphology, fitness, and motor coordination as part of a selection strategy in the search for international youth soccer players (age 15-16 years). Journal of Sports Sciences, 30(15), 1695-1703.

Wallace, J. L., \& Norton, K. I. (2013). Evolution of world cup soccer final games 1966-2010: Game structure, speed and play patterns. Journal of Science and Medicine in Sport, 17(2), 223-228.

Williams, A. M., \& Reilly, T. (2000). Talent identification and development in soccer. Journal of Sports Sciences, 18(9), 657-667.

Wilson, J. G. (2017). Talent identification and development of youth athletes in football. Journal of Australian Strength and Conditioning, 25(7), 73-78.

Woods, C. T., Joyce, C., \& Robertson, S. (2015). What are talent scouts actually identifying? Investigating the physical and technical skill match activity profiles of drafted and nondrafted U18 Australian footballers. Journal of Science and Medicine in Sport, 19 (5), 419423. 